\title{
Isolation, biochemical and molecular characterization of 2-chlorophenol-degrading Bacillus isolates
}

\author{
Roda F. Al-Thani ${ }^{1}$, Desouky A.M. Abd-El-Haleem ${ }^{1,2 \star}$ and Mona Al-Shammri ${ }^{1}$ \\ ${ }^{1}$ Biological Sciences Department, College of Arts and Sciences, Qatar University, Doha, Post Code 2713, Qatar. \\ ${ }^{2}$ Environmental Biotechnology Department, Genetic Engineering and Biotechnology Institute, Mubarak City for Scientific \\ Research and Technology Applications, New-Burgelarab City, Alexandria, Egypt. \\ Accepted 30 October, 2007
}

\begin{abstract}
Pure cultures of 2-chlorophenol degrading bacteria were isolated from a natural enrichment that may be adapted to chlorophenols in the industrial zone at Umm-Saied city (Qatar). The bacteria were identified by 16S rDNA analysis, using PCR with universal primers. Comparative analysis of the 16S rDNA sequence ( $550 \mathrm{bp})$ in the GenBank database revealed that these bacteria are related to the genus Bacillus. Molecular heterogeneity among 2-chlorophenol-degrading bacteria was investigated using REP-PCR chromosomal fingerprinting and correlated with antibiotic profile analysis. REP-PCR results strongly confirmed that the bacterial isolates from different Qatari soils produced different fingerprinting patterns. The distribution of phenol hydroxylase catabolic gene among examined isolates revealed that three isolates out of six yielded positive PCR products. Degradation of 2-chlorophenol was studied using theses cultures in liquid medium under aerobic conditions, at initial concentrations of $0.25-2.5$ $\mathrm{mM}$ 2-chlorophenol. Undegraded 2-chlorophenol was quantified by high-performance liquid chromatography (HPLC). Degradation rates by isolates could be determined at concentrations up to 1.5 $\mathrm{mM}$. However, higher concentrations of 2-chlorophenol $(2.5 \mathrm{mM})$ were inhibitory to cell growth.
\end{abstract}

Key words: Bacillus, biodegradation, chlorophenol, Qatar.

\section{INTRODUCTION}

Chlorinated phenols are common environmental contaminants; they have been extensively used as biocides, mainly as wood preservatives (Abd-El-Haleem et al., 2002). Chlorinated phenols and other chlorinated phenollic compounds are also formed as by-products when chlorine is used for bleaching of pulp (Kringstad and Lindstrom, 1984) and for disinfection of drinking water and waste water containing phenols (Ahlborg and Thunberg, 1980; Detrick, 1977).

Chlorinated phenols are also formed during combustion of organic matter (Ahling and Lindskog, 1982) and as biological breakdown products of chlorophenoxyacetic

*Corresponding author. E-mail: abdelhaleemm@yahoo.de. Tel: 009744852702. acid herbicides (Haggblom, 1990; Reineke and Knackmuss, 1988). A range of chlorinated organic compounds including chlorophenols can be produced by biologic chlorination as well (Neidleman and Geigert, 1986). Therefore, in the last few years, contamination of the environment by chlorinated aromatic compounds has been the subject of increased concern.

In water, chlorophenols sorb onto particulate material and, if not degraded, eventually end up in sediments. Chlorinated phenolics have been found to accumulate in freshwater and marine environments where they may attain concentrations of tens of milligrams per kilogram of dry sediment. In general, biological methods are preferable methods to treat aromatic compounds because it is economical, and there is a low possibility of the production of byproducts (Marcos et al., 1997). In this concern, several microorganisms used are usually aerobes, including Acinetobacter (Abd-El-Haleem et al., 2002), Pseudo- 
monas putida (Tarık and Ermine, 2004), Ochromonas sp. (Semple and Cain, 1996), and Rhodococcus sp. (Bergauer et al., 2005). These aerobes are more efficient at degrading toxic compounds because they grow faster than anaerobes and usually transform organic compounds to inorganic compounds.

Despite the fact that microbial degradation of chlorophenols has been investigated for many years, there is still considerable interest in the metabolic capacity of bacteria able to degrade chlorophenols within indigenous microbial consortia in various ecosystems (Annachhatre and Gheewala, 1996; Solyanikova and Golovleva, 2004). Moreover, the indigenous bacteria adapted to chlorophenols in the aeration pond were proposed for application to the biological waste water treatment (Matafonova et al., 2006). Most investigations are concerned with studying pathways and enzymes involved in biodegradation of chlorophenols, using culture collection strains, or with using engineered aerobicanaerobic systems to improve biodegradability. The aim of the present work was to investigate 2-chlorophenol degrading bacteria newly isolated from different Qatari polluted soils.

\section{MATERIALS AND METHODS}

\section{Sampling enrichment culturing and soil analysis}

Five soil samples were collected from different Qatari Ecosystems; one sample from Al-Ruwais, one sample from Al-Wakrah and three samples from different sites at the industrial zone at Umm-Saied city. Directly, after collection, soils were kept at $4^{\circ} \mathrm{C}$ until used. Later, soil samples were prepared for culturing by mixing $50 \mathrm{~g}$ moist weight with agitation in sterile distilled water $(1: 1 \mathrm{w} / \mathrm{v})$ for $1 \mathrm{~h}$ at room temperature.

Samples $(1 \mathrm{ml})$ were used to inoculate $100 \mathrm{ml}$ flasks containing 25 $\mathrm{ml}$ of minimal salt medium (MP) $\left(2.75 \mathrm{~g}\right.$ of $\mathrm{K}_{2} \mathrm{HPO}_{4}, 2.25 \mathrm{~g}$ of $\mathrm{KH}_{2} \mathrm{PO}_{4}, 1 \mathrm{~g}$ of $\left(\mathrm{NH}_{4}\right)_{2} \mathrm{SO}_{4}, 0.2 \mathrm{~g}$ of $\mathrm{MgCl} .6 \mathrm{H}_{2} \mathrm{O}, 0.1 \mathrm{~g}$ of $\mathrm{NaCl}$, $0.02 \mathrm{~g}$ of $\mathrm{FeCl}_{3} .6 \mathrm{H}_{2} \mathrm{O}, 0.01 \mathrm{~g}$ of $\mathrm{CaCl}_{2}, \mathrm{pH} 7.0$ and $\mathrm{H}_{2} \mathrm{O}$ to $1 \mathrm{~L}$ ) supplemented with $1 \mathrm{mM}$ 2-chlorophenol. Enrichments were incubated with shaking (125 rpm) at $30^{\circ} \mathrm{C}$ for $96 \mathrm{~h}$. Subsequently, pure cultures of 2-chlorophenol degrading bacteria were isolated by cycles of re-plating onto MP/2-chlorophenol agar plates. Out of 20 bacterial colonies appeared only with soil samples from Al-Ruwais (S1) and soil sample from Al-Wakrah (S2), six single colonies of the isolated chlorophenol-utilizing bacteria were selected randomly for further studies. Pure cultures were stored in $50 \mathrm{mM} \mathrm{KH}_{2} \mathrm{PO}_{4}$ : $\mathrm{K}_{2} \mathrm{HPO}_{4}$ buffer $(\mathrm{pH} 7.2)$ containing $20 \%(\mathrm{v} / \mathrm{v})$ glycerol at $-70^{\circ} \mathrm{C}$.

Analysis of the two soil samples (S1 and S2) that gave colonies after the enrichment culturing procedure was performed. The analysis was performed using the central lab facilities at Qatar University. Analysis was carried out using the inductively coupled plasma mass spectrometry ICP/Ms Series 7500 . It can measure trace elements as low as one part per trillion (ppt) or quickly scan more than 70 elements to determine the composition of an unknown sample.

\section{Biochemical analysis of the isolates}

Dioxygenase activity was performed using the indigo test. Bacterial colonies were pre-grown on LB agar plates ( $5 \mathrm{~g}$ of yeast extraction, $10 \mathrm{~g}$ of Casein/peptone, $10 \mathrm{~g} \mathrm{NaCl}, 15 \mathrm{~g}$ agar and $\mathrm{H}_{2} \mathrm{O}$ to $1 \mathrm{~L}$ ) and then indol crystals were plated on the lid of the Petri dish. After 1 day incubation at room temperature, colonies that produce a blue color were scored positive. The activity of catalase was determined by the appearance of air bubbles after addition of a drop of $30 \%$ hydrogen peroxide solution to an overnight grown single bacterial colony. To determine the ability of isolates to hydrolyze starch, 50 $\mu \mathrm{L}$ of liquid cultures of the isolated strains were dropped on starch Petri dishes (Per liter, $3 \mathrm{~g}$ meat extract, $10 \mathrm{~g}$ starch and $14 \mathrm{~g}$ agar). After one day, the inhibition zones were determined. For casine hydrolysis, $50 \mu \mathrm{L}$ of liquid cultures of the isolated strains were dropped on casein Petri dishes (10 $\mathrm{g}$ casein, $14 \mathrm{~g}$ agar dissolved in $1 \mathrm{~L}$ and then autoclave). After one day, the inhibition zones were determined. In addition, the six isolated stains were subjected to classical gram staining.

\section{Molecular analysis of the isolates}

DNA extraction of all isolates was performed by using AMSHAGE DNA extraction kit (Abd-El-Haleem, 2005). To detect phenol hydroxylase DNA fragments coding for the largest subunit of multicomponent phenol hydroxylases $(\mathrm{LmPH})$ were amplified by using the Applied Biosystems thermal cycler and $50 \mu \mathrm{l}$ mixtures containing $25 \mu \mathrm{l}$ of the $2 \times$ PCR master mixes (Cinnagen Inc.), 100 pmol of each primer, and $50 \mathrm{ng}$ of template DNA. The primers used are phe3r (5-CAGSCGRTWACCKCGCCAGAACC-3) and phe1f (5GARGGCATCAARATY-3) (Futamata et al. 2001). The PCR conditions for the two primer sets phe1f and phe3r, were as follows: step 1, 10 min of activation at $94^{\circ} \mathrm{C}$; step 2, 35 cycles consisting of $1 \mathrm{~min}$ at $94^{\circ} \mathrm{C}, 1 \mathrm{~min}$ at $50^{\circ} \mathrm{C}$, and $1 \mathrm{~min}$ at $72^{\circ} \mathrm{C}$; step $3,10 \mathrm{~min}$ of extension at $72^{\circ} \mathrm{C}$. The PCR products were checked by electrophoresis through $1.2 \%(\mathrm{w} / \mathrm{v})$ agarose gel in TBE buffer and then staining with ethidium bromide $(0.5 \mu \mathrm{g} / \mathrm{ml}$ : Sigma, Bornem, Belgium) and then visualized and photographed in Multilmage light cabinet (Alpha Innotech Corporation, USA). The sizes of the amplified products were assessed by comparison with a commercial weight marker. The sizes of the amplified products were assessed by comparison with a commercial weight marker (Invitrogen, Netherlands).

\section{Comparative sequence analysis of 16S r DNA}

Molecular identification of the selected isolates was performed by the amplification of $16 \mathrm{~S}$ rDNA with eubacterial universal primers 27F and 1492R (Lane, 1991). Sequencing was performed using ABI PRISM dye terminator cycle sequencing kit with AmpliTaq DNA polymerase and an Applied Biosystems 373 DNA sequencer (Perkin-Elmer, Foster City, Calif.). The sequences were analysed using the CHECK CHIMERA and the SIMILARITY RANK programs of the Ribosomal Database Project (Altschul et al., 1990) also analysed using the BLAST program (National Centre for Biotechnology Information) to determine the closest available database sequences. Selected rDNA sequences were aligned using the Clustal W program (Shingler, 1996). Published sequences were obtained from GenBank. A phylogenetic tree was constructed using Clustal $W$ by distance matrix analysis and the neighbour-joining method (Saitou and Nei, 1987). Phylogenetic trees were displayed using TREEVIEW (Page, 1996).

\section{Genomic fingerprinting using REP-PCR based approach}

REP-PCR (Repetitive extragenic palindromic sequence PCR (REP$\mathrm{PCR}$ ) Fingerprinting patterns from bacterial genomic DNA were generated with BOX1 primer (Louws, 1994). Each isolate was grown on a phenol minimal agar plate for $48 \mathrm{~h}$, and a small amounts of cells from a colony were picked by a needle and sus- 
Table 1. Chemical analysis of the soil samples S1 and S2.

\begin{tabular}{|c|c|c|}
\hline \multirow{2}{*}{ Parameter } & \multicolumn{2}{|c|}{ Parameter concentration (ppm) } \\
\cline { 2 - 3 } & $\mathbf{S 1}$ & $\mathbf{S 2}$ \\
\hline $\mathbf{N a}$ & $\mathrm{Nil}$ & $\mathrm{Nil}$ \\
$\mathbf{M g}$ & 3 & 2.6 \\
$\mathbf{K}$ & 200 & 811 \\
$\mathbf{C a}$ & 100 & 82 \\
$\mathbf{C r}$ & 2 & 9.3 \\
$\mathbf{M n}$ & 5.4 & 640 \\
$\mathbf{F e}$ & 1 & 304 \\
$\mathbf{C O}$ & 2 & 1.6 \\
$\mathbf{N i}$ & $\mathrm{Nil}$ & 570 \\
$\mathbf{C u}$ & 1.2 & 13 \\
$\mathbf{Z n}$ & 2.3 & 5.8 \\
$\mathbf{N}$ & $\mathrm{Nil}$ & $\mathrm{Nil}$ \\
$\mathbf{P}$ & $\mathrm{Nil}$ & $\mathrm{Nil}$ \\
$\mathbf{F}$ & $\mathrm{Nil}$ & $\mathrm{Nil}$ \\
$\mathbf{B}$ & $\mathrm{Nil}$ & $\mathrm{Nil}$ \\
$\mathbf{P b}$ & $\mathrm{Nil}$ & $\mathrm{Nil}$ \\
$\mathbf{C}$ & $\mathrm{Nil}$ & $\mathrm{Nil}$ \\
\hline
\end{tabular}

pended in $25 \mu \mathrm{L}$ of MilliQ $\mathrm{H} 2 \mathrm{O}$. Cells were heated at $95^{\circ} \mathrm{C}$ for 10 min, immediately cooled on ice, and centrifuged. The PCR was performed in $50 \mu \mathrm{L}$ (as described above). The reaction were performed in a DNA thermal cycler, 1 cycle at $95^{\circ} \mathrm{C}$ for $6 \mathrm{~min}$ followed by 30 cycles at $94^{\circ} \mathrm{C}$ for $1 \mathrm{~min}, 53^{\circ} \mathrm{C}$ for $1 \mathrm{~min}, 65^{\circ} \mathrm{C}$ for 8 min, $68^{\circ} \mathrm{C}$ for $2 \mathrm{~min}$, and a final extension at $65^{\circ} \mathrm{C}$ for $15 \mathrm{~min}$ prior to cold storage at $4^{\circ} \mathrm{C}$. REP-PCR products samples were separated by electrophoresis through $1.5 \%$ agarose gel, stained, visualized and photographed as described above.

\section{Nucleotide sequence accession numbers}

The nucleotide sequence data reported in this study have been deposited in the NCBI nucleotide sequence databases (GenBank) under accession numbers EF611184, EF611183, EF611182, EF611181, EF611180 and EF611179.

\section{Growth inhibition assay}

This test was performed to determine the inhibition effect of various 2-chlorophenol concentrations on the growth of the isolated bacterial strains after $24 \mathrm{~h}$ of incubation. Experiments were performed by inculcate $2.5 \mathrm{ml}$ of overnight culture of each strain into a flask (100 $\mathrm{ml}$ ) containing $22.5 \mathrm{ml}$ of MP media supplanted individually with chlorophenol concentrations $0.25,0.5,1,1.5,2$ and $2.5 \mathrm{mM}$. Cultures were incubated aerobically with shaking $(150 \mathrm{rpm})$ at $35^{\circ} \mathrm{C}$. Optical densities were then measured by spectrophotometer (Jenway Ltd) at $600 \mathrm{~nm}$ for one week.

\section{Determination of the biodegradation rate}

Chlorophenol degradation experiments were performed in shake flasks (50 ml of MP medium containing 50 ppm 2-chlorophenol) for $96 \mathrm{~h}$ of incubation with free cells of each strain. To measure the degradation rates, chlorophenols were quantified each $24 \mathrm{~h}$ by high-performance liquid chromatography. Prior to analysis, the sam- ples $(0.3$ to $0.5 \mathrm{ml}$ ) were acidified with $10 \mu \mathrm{L}$ of $1 \mathrm{~N} \mathrm{HCl}$, centrifuged, and filtered $(0.45 \mu \mathrm{m})$. Analysis was performed with a Beckman 332 LC chromatograph (Beckman Instruments, Palo Alto, Calif.) equipped with a Spherisorb C-18 column (250 by $4.6 \mathrm{~mm}$; Supelco Inc., Bellefonte, Pa.), with UV detection at $280 \mathrm{~nm}$, and using a solvent system of methanol $(60 \%$, vol $/$ vol $)$-water $(38 \%$, $\mathrm{vol} / \mathrm{vol})$-acetic acid ( $2 \%$, vol $/ \mathrm{vol})$ at a flow rate of $1 \mathrm{ml} / \mathrm{min}$.

\section{RESULTS}

\section{Soil analysis}

S1 and S2 soil samples which gave bacterial colonies after enrichment culturing procedure were chemically analyzed as descried above in the materials and methods section. The analysis results are presented in Table 1 at which the soil sample S2 (Al-Wakrah) recorded higher values for both heavy metals and cations content when compared to the soil sample S1 (El-Ruwais).

\section{Biochemical analysis of the isolates}

As shown in Table 2, Gram-staining revealed that all selected isolates are Gram-positive bacteria. No dioxygenase activity was recorded for all tested isolates (data not shown). Catalase and casine assays showed positive results only with isolates 6 and 3 , respectively. In contrast, all tested isolates recorded positive results with the starch hydrolysis assay. Antibiotic resistant profile showed that isolates 3 and 6 are resistant to penicillin, and isolate 2 is resistant only to erythromycin.

\section{Molecular analysis of the selected bacterial isolates}

Chromosomal DNA of the bacterial isolates was extracted using AMSHAGE DNA extraction kit (Abd-ElHaleem 2005). As shown in Figure 1, the applied method was so effective and reliable that it resulted in relatively high DNA concentrations. Comparative sequence analysis of the $16 \mathrm{~S}$ ribosomal DNA ( 550 bp) of the isolates revealed that all isolates are closely related to the genus of Bacillus exhibiting similarity values ranging from 98-99\% (Figure 2). Two strains QUCASBSD-1 and QUCASBSD-2 are closely related to species of Bacillus ceruse, strains QUCASBSD-4, QUCASBSD-5 and QUCASBSD-6 relate to Bacillus thuringiensis. However, only strain QUCASBSD-3 is relates to species of Bacillus licheniformis. Molecular heterogeneity among the 2chlorophenol-degrading bacteria was investigated. As shown in Figure 3, REP-PCR profiles were able to discriminate among all isolates. It was able to recognize the six isolates into two groups; the first includes isolates QUCASBSD-1, QUCASBSD-3 and QUCASBSD-6, while the second group includes strains QUCASBSD-2, QUCASBSD-4 and QUCASBSD-5, respectively. The distribution of phenol hydroxylase catabolic genes among 
Table 2. Biochemical characterization of the bacterial isolates.

\begin{tabular}{|c|c|c|c|c|c|c|c|c|c|c|c|}
\hline \multirow[b]{2}{*}{ Sample } & \multirow[b]{2}{*}{ Isolate } & \multirow{2}{*}{$\begin{array}{l}\text { Gram } \\
\text { stain }\end{array}$} & \multirow{2}{*}{$\begin{array}{c}\text { Indigo } \\
\text { test }\end{array}$} & \multirow{2}{*}{$\begin{array}{l}\text { Catalase } \\
\text { reaction }\end{array}$} & \multirow{2}{*}{$\begin{array}{c}\text { Casein } \\
\text { hyd. }\end{array}$} & \multirow{2}{*}{$\begin{array}{l}\text { Starch } \\
\text { hyd. }\end{array}$} & \multicolumn{5}{|c|}{$\begin{array}{c}\text { Antibiotic } \\
\text { resistance profile* }\end{array}$} \\
\hline & & & & & & & $T$ & $\mathbf{P}$ & $E$ & $\mathbf{G}$ & $\mathbf{K}$ \\
\hline \multirow[t]{3}{*}{$\mathrm{S} 1$} & 1 & + & - & + & - & + & + & + & + & + & + \\
\hline & 2 & + & - & + & - & + & + & + & - & + & + \\
\hline & 3 & + & - & + & + & + & + & - & + & + & + \\
\hline \multirow[t]{3}{*}{ S2 } & 4 & + & - & + & - & + & + & + & + & + & + \\
\hline & 5 & + & - & + & - & + & + & + & + & + & + \\
\hline & 6 & + & - & - & - & - & + & - & + & + & + \\
\hline
\end{tabular}

${ }^{*} \mathrm{~T}=$ tetracycline, $\mathrm{P}=$ Penecillin, $\mathrm{E}=$ erythromycin, $\mathrm{G}=$ Gentamicine, and $\mathrm{K}=$ Kanaycin

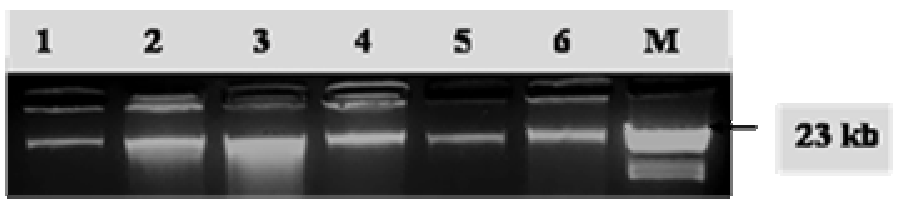

Figure 1. Agarose gel electrophoresis shows DNA extracts of the six selected isolates (QUCASBSD-1 to QUCASBSD-6) using AMSHAGE DNA extraction kit. Lane M, DNA ladder.

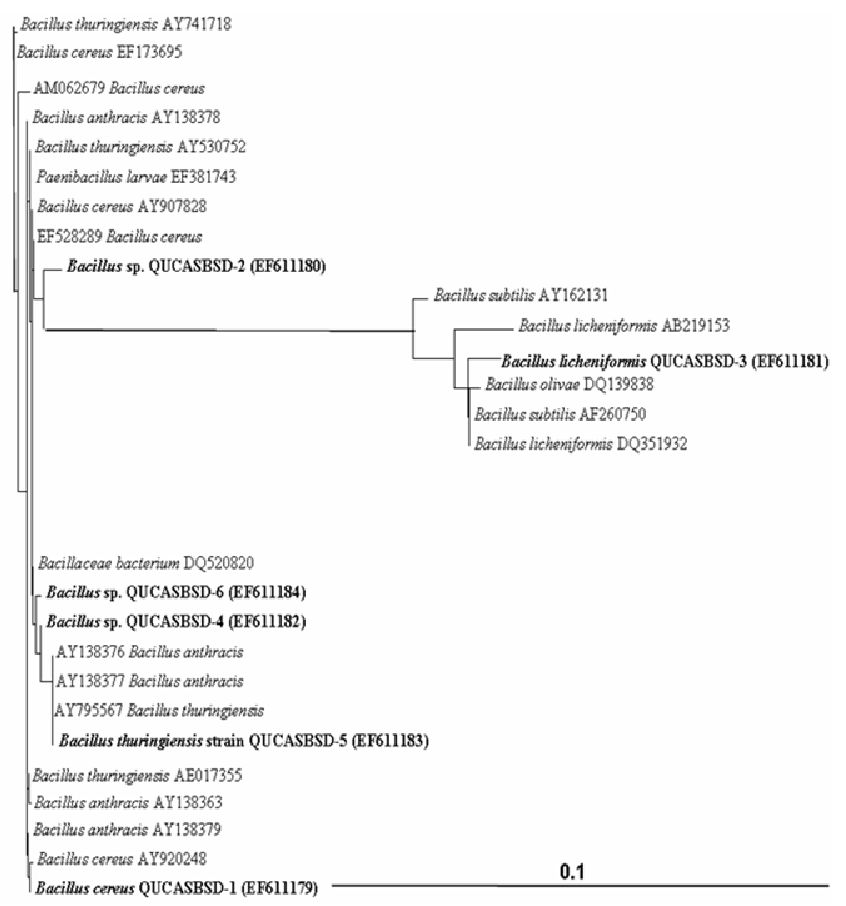

Figure 2. Phylogenetic tree showing the relationships among isolated strains (in boldface) and published 16S rDNA sequences (their GenBank accession numbers are present in the brackets).

examined strains revealed that strains QUCASBSD-3, QUCASBSD-5 and QUCASBSD-6 yielded positive PCR amplified products of $\mathrm{LmPH}$ genes in the range of expect-

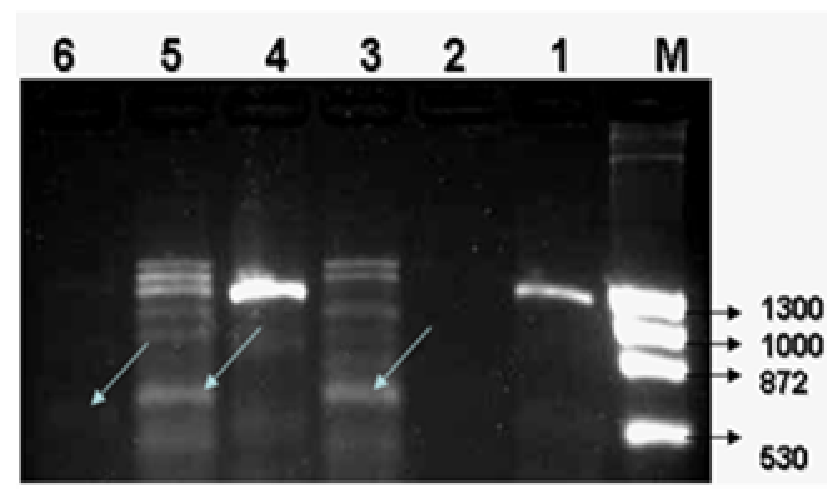

Figure 3. PCR detection of bacterial multicomponent phenol hydroxylases (LmPHs) in the selected isolates (QUCASBSD-1 to QUCASBSD-6), Lane M DNA ladder.

ed sizes ( 700 bp). No PCR amplified bands were observed with isolates QUCASBSD-1, QUCASBSD-2 and QUCASBSD-4 (Figure 4).

\section{Biodegradation experiments}

With this investigation, we demonstrated the 2chlorophenol-degradation capability of the isolated Bacillus species. The isolated Bacillus strains exhibited degradation potential for 2-chlorophenol at concentrations up to $1.5 \mathrm{mM}$ in liquid medium under aerobic conditions (Figure 5). At concentrations of 2-chlorophenol between 0.25 and $1.5 \mathrm{mM}$, the Bacillus strains showed increasing rates of degradation; however, higher 2chlorophenol concentrations $(2.5 \mathrm{mM})$ were inhibitory to growth. As shown in Figure 6, after four days of growth the isolates were able to degrade varying amounts of 2chlorophenol.

\section{DISCUSSION}

The present work describes the isolation of native bacterial strains from different Qatari ecosystems with the 


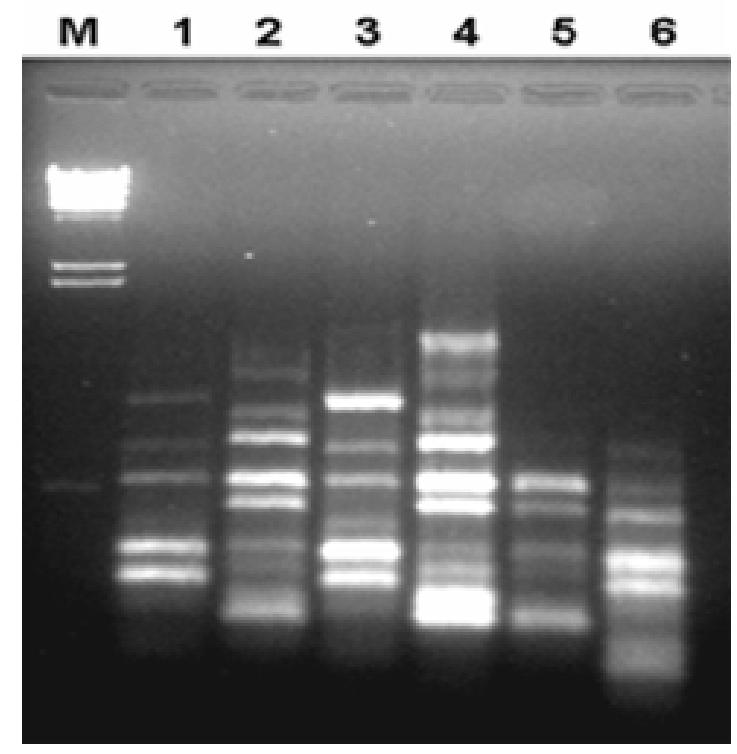

Figure 4. Gel electrophoresis (2\%) of REP-PCR fingerprint patterns of isolates from QUCASBSD-1 to QUCASBSD-6 (Lanes 1 - 6, respectively). Lane M, DNA ladder.

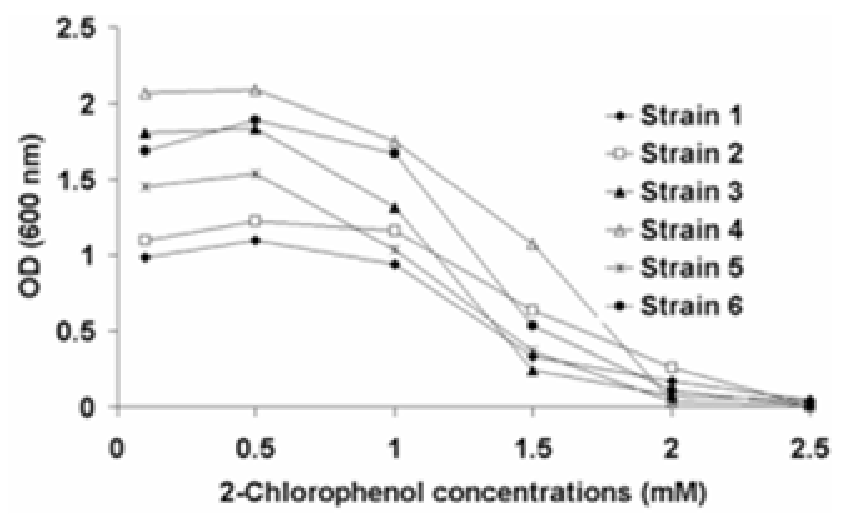

Figure 5. Growth inhibition assay of the 2-chlorophenoldegrading Bacillus isolates for $24 \mathrm{~h}$.

ability to degrade one of the most important phenol derivatives (2-chlorophenol) as a sole carbon source based on culture enrichment technique. Due to its simplicity compared with the other isolation tools, it has been reported that culture enrichment methods are highly selective resulting in the isolation of a few microbial species from various natural microbial populations (Dunbar et al., 1997).

All of 2-chlorophenol-degrading bacteria described in this work were Gram-positive spore-forming rods with dimensions $1.8-3.5 \mathrm{~mm}$. They were catalase positives with exception of strain QUCASBSD-6. However, no relationships were observed between the dioxygenase test (indigo assay) and the biodegradation process. Indol conversion to indigo is considered representative of dio-

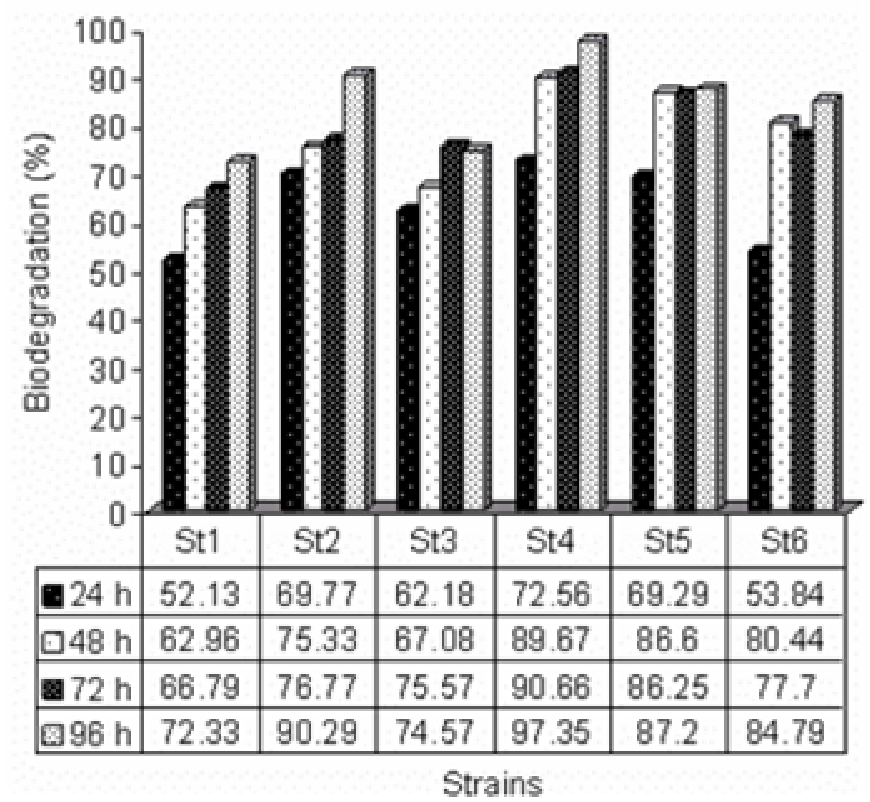

Figure 6. 2-chlorophenol biodegradation percentage profile by freely suspended cells of six isolated bacterial strains St-1 to St 6 (QUCASBSD-1 to QUCASBSD-6)

xygenase activity. The indol conversion was previously shown by aromatic ring dioxygenase from monocyclic aromatic hydrocarbon degraders (Wubbolts et al., 1994).

Comparative sequence analysis of the 16S rDNA ( 550 bp) in the GenBank database revealed that the six bacterial isolates were most closely related each to other and to the genus Bacillus. Members of this genus, e.g. Bacillus stearothermophilus BR219 (Subramanian, 1992), Bacillus thermoglucosidasius A7 (Duffner et al., 2000), and Bacillus thermoleovorans strain A2 (Duffner and Muller, 1998; Feitkenhauer et al., 2001, 2003), were described to degrade phenol, cresols, nitrophenols, bromophenols. Bacillus strains also degrade 4-chlorobiphenyl (Saagua et al., 1998) and polychlorinated biphenyls (Kim et al., 2004). Phenol-degrading Bacillus sp. A2 was able previously to transform 2-chlorophenol at concentrations up to $1 \mathrm{mM}$ (Reinscheid et al., 1996). It was also observed that spores of the strain Bacillus subtilis IFO3335 can produce a laccase, catalyzing oxidation of such substituted phenols as (chloro)guaiacol, (chloro)metoxyphenols (Hirose et al., 2003). The degradative potential of $B$. cereus for several pollutants, such as azo dyes (Khehra et al., 2005), polycylic aromatic hydrocarbons (Kazunga et al., 2001; Tuleva et al., 2005), chlorobenzenes (Wang et al. 2003) and polyethoxylated nonylphenols (Di-Gioia et al., 2004), have been also examined.

The phylogenetic dendrogram generated on the basis of $16 \mathrm{~S}$ rDNA sequences revealed that bacterial isolates QUCASBSD-4, QUCASBSD-5 and QUCASBSD-6 are clearly separated into main cluster. Out of these results and the results of the soil analysis, it is possible to con- 
clude that each isolation sampling site has its own 2chlorophenol-degrading bacteria even if they are genetically closely related. Moreover, bacterial isolates also produced different REP-PCR fingerprint patterns. Compared with other conventional molecular biological methods, REP-PCR approach offers the advantages of ease of performance, rapid and sufficient results for species identification with small quantities of DNA (AbdEl-Haleem et al., 2002).

It is established that molecular approaches have expanded our knowledge of the diversity and distribution of microbial populations in the environment. Genes coding for catabolic enzymes such as methane monooxygenase (Henckel et al., 2000), ammonia monooxygenase (Pace et al., 1986), catechol dioxygenase (Okuta et al., 1998), and phenol hydroxylase (Watanabe et al., 1998) have also been retrieved from the environment in order to gain insight into the genetic diversity of catabolic populations. It is currently expected that such genetic information could aid in understanding and advancing bioremediation (Watanabe and Baker, 2000).

In phenol-degrading bacteria, two types of phenol hydroxylase are known, single-component and multicomponent enzymes (LmPHs) (Harayama et al., 1992). Among them, multicomponent enzymes are considered the major ones in the environment (Watanabe et al., 1998). Therefore, in the present study, we analyzed genes for the largest subunit of multicomponent phenol hydroxylases using previously designed group-specific PCR primers for LmPHs (Futamata et al., 2001). As shown in Figure 2, three bacterial isolates QUCASBSD-3, QUCASBSD-5 and QUCASBSD-6 yielded positive PCR products with phenol-degrading genes. However, these results do not mean that the other three isolates QUCASBSD-2, QUCASBSD-4 and QUCASBSD-5 are not 2-chlorophenol degraders. It is known that the degradation of phenol and its derivatives takes place aerobically through two main metabolic pathways; initiated by ortho- or meta- cleavage (Zaki, 2006). The enzymes phenol hydroxylase and catechol 1,2-dioxygenase or 2,3-dioxygenase catalyze the first and the second steps of phenol degradation, respectively (Gaal and Neujahr, 1979) which need to be covered for the isolated strains in next studies.

In conclusion, our results suggest that the bacterial community in both $\mathrm{S} 1$ and $\mathrm{S} 2$ soil samples contain strains such of genus Bacillus, which exhibit high potential for effective degradation of 2-chlorophenol under aerobic conditions. The contribution of such species, derived from contaminated sites, can be better understood by investigating their degradative potential under laboratory conditions; this serves as a major experimental strategy for understanding bioremediation processes (Demnerova et al., 2005). If the growth of these organisms can be selectively supported in the environment, they will contribute to the degradation of 2-clorophenol in a wide range of concentrations, up to $2.5 \mathrm{mM}$, and there- fore decrease the impact of pollutants.

\section{REFERENCES}

Abd-El-Haleem D (2005). DNA extraction kit from bacteria fungi, water and whole blood. Egyptian patent office (issued patent number 23525)

Abd-El-Haleem D, Moawad H, Zaki E, Zaki S (2002). Molecular characterization of phenol degrading bacteria isolated from different Egyptian ecosystems. Microbiol. Ecol. 43: 217-224.

Ahlborg G, Thunberg T (1980). Chlorinated phenols: occurrence, toxicity, metabolism, and environmental impact. Crit. Rev. Toxicol. 7: 1-35.

Ahling B, Lindskog A (1982). Emissions of chlorinated organic substances from combustion, In Hutzinger 0, Frei RW, Merian E, Pocchiari $F$ (ed.), Chlorinated dioxins and related compounds. Impact on the environment. Pergamon Press, Oxford. p. 215-225.

Altschul SF, Gish W, Miller W, Myers EW, Lipman DJ (1990). Basic local alignment search tool. J. Mol. Biol. 215: 403-410

Annachhatre AP, Gheewala SH (1996). Biodegradation of chlorinated phenolic compounds. Biotechnol Adv. 14(1): 35-56.

Bergauer P, Fonteyne PA, Nolard N, Schinner F, Margesin R (2005). Biodegradation of phenol and phenol-related compounds by psychrophilic and cold-tolerant alpine yeasts. Chemosphere. 59: 909-918

Demnerova K, Mackova M, Spevakova V, Beranova K, Kochankova L, Lovecka P, Ryslava E, Macek T (2005). Two approaches to biological decontamination of groundwater and soil polluted by aromatics-characterization of microbial populations. Int. Microbiol. 8: 205-211.

Di-Gioia D, Fambrini L, Coppini E, Fava F, Barberio C (2004). Aggregation-based cooperation during bacterial aerobic degradation of polyethoxylated nonylphenols. Res. Microbiol. 155: 761-769.

Duffner F, Kirchner U, Bauer M, Muller R (2000). Phenol/cresol degradation by the thermophilic Bacillus thermoglucosidasius A7: cloning and sequence analysis of five genes involved in the pathway. Gene. 256: 215-221.

Duffner F, Muller R (1998). A novel phenol hydroxylase and catechol 2,3-dioxygenase from the thermophilic Bacillus thermoleovorans strain A2: nucleotide sequence and analysis of the genes. FEMS Microbiol. Lett. 161: 37-45.

Dunbar J, White S, Forney L (1997). Genetic diversity through the looking glass: effect of enrichment bias. Appl. Environ. Microbiol. 63: 1326-1331.

Feitkenhauer H, Schnicke S, Muller R, Markl H (2001). Determination of the kinetic parameters of the phenol-degrading thermophile Bacillus themoleovorans sp. A2. Appl. Microbiol. Biotechnol. 57: 744-750.

Feitkenhauer H, Schnicke S, Muller R, Markl H (2003). Kinetic parameters of continuous cultures of Bacillus thermoleovorans $\mathrm{sp}$. A2 degrading phenol at 65 1C. J. Biotechnol. 103: 129-135.

Futamata H, Harayama S, Watanabe K (2001). Group-specific monitoring of phenol hydroxylase genes for a functional assessment of phenol-stimulated trichloroethylene bioremediation. Appl. Environ. Microbiol. 67: 4671-4677.

Gaal A, Neujahr HY (1979). Metabolism of phenol and resorcinol in Trichosporon cutaneum. J. Bacteriol. 137: 13-21.

Haggblom M (1990). Mechanisms of bacterial degradation and transformation of chlorinated monoaromatic compounds. J. Basic Microbiol. 30: 115-141.

Harayama S, Kok M, Neidle EL (1992). Functional and evolutionary relationships among diverse oxygenases. Ann. Rev. Microbiol. 46: 565-601.

Henckel T, Roslev P, Conrad R (2000). Effects of $\mathrm{O} 2$ and $\mathrm{CH} 4$ on presence and activity of the indigenous methanotrophic community in rice field soil. Environ. Microbiol. 2: 666-679.

Hirose J, Nasu M, Yokoi H (2003). Reaction of substituted phenols with thermostable laccase bound to Bacillus subtilis spores. Biotechnol. Lett. 25: 1609-1612

Kazunga C, Aitken M, Gold A, Sangaiah R (2001). Fluoranthene- 2,3and-1,5-diones are novel products from the bacterial transformation of fluoranthene. Environ. Sci. Technol. 35: 917-922. 
Khehra M, Saini H, Sharma D, Chadha B, Chimni S (2005). Comparative studies on potential of consortium and constituent pure bacterial isolates to decolorize azo dyes. Water Res. 39: 5135-5141.

Kim A, Pestsov G, Yadgarov K, Dzhumaniyazova G, Zinov'ev P, Dzhuraeva G, Abdukarimov A, Gins V (2004). Microorganisms degrading polychlorinated biphenyls. Appl. Biochem. Microbiol. 40: 70-73.

Kringstad K, Lindstrom K (1984). Spent liquors from pulp bleaching. Environ. Sci. Technol. 18: 236A-248A.

Lane DJ (1991). 16S/23S rRNA sequencing. In E. Stackebrandt, and M. Goodfellow (ed.), Nucleic acid techniques in bacterial systematics. John Wiley \& Sons, Inc., New York, N.Y pp. 115-148.

Louws FJ, Fulbright DW, Taylor SC, de Bruijn FJ (1994). Specific genomic fingerprints of phytopathogenic Xanthomonas and Pseudomonas pathovars and strains generated with repet-proteindue binding. Anal. Biochem. 72: 248-254.

Marcos ML, Garces MM, Alonso L, Juste S, Carretero P, Blanco J, Garcia F, Perez R, Herrero D. (1997). Occupational allergic contact dermatitis from homatropine and phenylephrine eyedrops. Contact Dermatitis; 37:189-196.

Matafonova G (2006). Degradation of 2,4-dichlorophenol by Bacillus sp. isolated from an aeration pond in the Baikalsk pulp and paper mill. Int. Biodeterior. Biodegradation 58: 209-212.

Neidleman SL, Geigert J (1986). Biological halogenation: roles in nature, potential in industry. Endeavour. 11: 5-15.

Okuta A, Ohnishi K, Harayama S (1998). PCR isolation of catechol 2,3dioxygenase gene fragments from environmental samples and their assembly into functional genes. Gene. 212: 221-228.

Pace NR, Stahl DA, Lane DL, Olsen GJ (1986). The analysis of natural microbial populations by rRNA sequences. Adv. Microbiol. Ecol. 9: 1-55.

Page RD (1996). TREEVIEW: an application to display phylogenetic trees on personal computers. Comput. Appl. Biosci. 12: 357-358

Reinscheid U, Bauer M, Muller R (1996). Biotransformation of halophenols by a thermophilic Bacillus sp. Biodegradation. 7: 455461.

Saagua M, Vieira G, Paveia H, Anselmo A (1998). Isolation and preliminary characterization of Bacillus sp. MCS, a gram-positive 4chlorobiphenyl degrading bacterium. Int. Biodeterior. Biodegradation 42: 39-43.

Saitou N, Nei M (1987). The neighbour-joining method: a new method for reconstructing phylogenetic trees. Mol. Biol. Evol. 4: 406-425.

Semple KT, Cain RB (1996). Biodegradation of phenols by the alga Ochromonas danica. Appl. Environ. Microbiol. 62: 1265-1273.
Shingler V (1996). Molecular and regulatory checkpoints in phenol degradation by Pseudomonas sp. CF600. In Nakazawa T, Furukawa $\mathrm{K}$, Haas D, Silver S (ed.), Molecular biology of pseudomonads. American Society for Microbiology, Washington, D.C. pp. 153-164

Solyanikova IP, Golovleva LA (2004). Bacterial degradation of chlorophenols: pathways, biochemica, and genetic aspects. J. Environ. Sci. Health B. 39:333-51.

Subramanian R (1992). Kinetics of growth and catechol production by Bacillus stearothermophilus. Masters Abstracts International. 30: 1405-1412.

Tarık A, Emine B, Tanju M, Ülkü M (2004). Kinetics model for growth of Pseudomonas putida $\mathrm{F} 1$ during benzene, toluene and phenol biodegradation. Process Biochem. 39: 983-988.

Tuleva B, Christova N, Jordanov B, Nikolova-Damyanova B, Petrov P (2005). Naphthalene degradation and biosurfactant activity by Bacillus cereus 28BN. Z. Naturforsch., C, J. Biosci. 60: 577-582.

Wang L, Zhou Q, Zhang BS, Li ZL, Chua H, Ren DM (2003). The biodegradation of 1,3-dichlorobenzene by an adapted strain Bacillus cereus PF-11 derived from town-gas industrial effluent. J. Environ. Sci. Health A Tox. Hazard Subst. Environ. Eng. 38: 1837-1848.

Watanabe K, Baker PW (2000). Environmentally relevant microorganisms. J. Biosci. Bioeng. 89: 1-11.

Watanabe K, Teramoto M, Futamata H, Harayama S (1998). Molecular detection, isolation, and physiological characterization of functionally dominant phenol-degrading bacteria in activated sludge. Appl. Environ. Microbiol. 64: 4396-402.

Wubbolts MG, Reuvekamp P, Witholt B (1994). TOL plasmid-specified xylene oxygenase is a wide substrate range monooxygenase capable of olefin epoxidation. Enzyme Microb. Technol. 16: 608-615.

Zaki S (2006). Detection of meta- and ortho-cleavage dioxygenases in bacterial phenol-degraders. J. Appl. Sci. Environ. Manage. 10: 7581. 